\title{
Serum procalcitonin in bacterial \& non-bacterial meningitis in children
}

\author{
Shipra Chaudhary * (D), Nisha Keshary Bhatta, Madhab Lamsal, Rajendra Kumar Chaudhari and Basudha Khanal
}

\begin{abstract}
Background: Bacterial meningitis is a paediatric emergency with high mortality and morbidity requiring prompt diagnosis and treatment. Clinically, it is often difficult to differentiate between bacterial and non-bacterial meningitis. Several studies have demonstrated the raised values of serum procalcitonin (PCT) in bacterial infections including meningitis but without definite cut-off guidelines. Hence, this study was done to evaluate serum PCT as a marker to differentiate bacterial and non-bacterial meningitis in children and assess its efficacy.

Methods: It was a cross-sectional study done over a period of 5 months (Aug 2016-Dec 2016) in the department of Paediatrics, B P Koirala Institute of Health Sciences (BPKIHS). Fifty children aged 3 months to 15 years with suspected meningitis were enrolled and investigated with relevant investigations like complete blood counts, and cerebrospinal fluid (CSF) analysis along with serum PCT. Patients were classified into bacterial (22) and non-bacterial meningitis (28) according to clinical \& CSF findings and data analysed using SPSS software.

Results: Serum PCT levels were significantly higher in bacterial meningitis group (median $=2.04(1.2-3.18) \mathrm{ng} / \mathrm{ml}$ ) compared with non-bacterial meningitis (median $=0.35(0.18-0.35) \mathrm{ng} / \mathrm{ml}$ ); $p<0.001$. The sensitivity and specificity of serum PCT in diagnosis of bacterial meningitis at cut-off level of $0.5 \mathrm{ng} / \mathrm{ml}$ were $95.45 \%$ and $84.61 \%$ respectively. Procalcitonin showed maximum area under receiver operating characteristics (ROC) curve $0.991(0.974-1.00)(p<0.001)$ compared to total leukocyte count and CSF cytochemistry.

Conclusion: Serum PCT has high sensitivity and specificity for early diagnosis of bacterial meningitis in children. Hence it can be a useful adjunct in differentiating bacterial and non-bacterial meningitis for prompt and better management of the children.
\end{abstract}

Keywords: Procalcitonin, Bacterial meningitis, Leukocyte count, Cerebrospinal fluid

\section{Background}

Meningitis is one of the most common central nervous system (CNS) infections encountered in infants and children. The source of infection in meningitis can be bacterial, viral, fungal, or parasitic in origin [1]. Bacterial meningitis is a paediatric emergency with high mortality and morbidity. Hence it must be diagnosed and treated promptly. But the similar clinical presentation often makes it difficult to differentiate bacterial and non-bacterial aetiologies in children $[2,3]$.

Currently, cerebrospinal fluid (CSF) analysis has been considered the gold standard for diagnosing bacterial meningitis, along with biomarkers like C-reactive protein (CRP) and white blood cell count (WBC) [2]. However,

\footnotetext{
* Correspondence: nowshipra@gmail.com

B P Koirala Institute of Health Sciences, Dharan, Nepal
}

clinical criteria, gram staining, and bacterial antigen testing of CSF as well as the classic biological markers in blood (CRP, WBC, and neutrophil count) or CSF (protein level, glucose level, WBC, and neutrophil count) used alone do not offer $100 \%$ sensitivity and specificity for distinguishing bacterial and non-bacterial meningitis $[2,4]$. Moreover, two or more days of waiting is required to identify bacterial growth in CSF cultures $[4,5]$.

After intensive research for new and rapid diagnostic methods for differential diagnosis of meningitis, serum procalcitonin (PCT) has been demonstrated to be the best marker for diagnosis of sepsis that also correlates with the extent and severity of microbial invasion [6]. Procalcitonin is now considered to be clinically most useful and superior to CRP due to its high diagnostic

(c) The Author(s). 2018 Open Access This article is distributed under the terms of the Creative Commons Attribution 4.0 International License (http://creativecommons.org/licenses/by/4.0/), which permits unrestricted use, distribution, and reproduction in any medium, provided you give appropriate credit to the original author(s) and the source, provide a link to the Creative Commons license, and indicate if changes were made. The Creative Commons Public Domain Dedication waiver (http://creativecommons.org/publicdomain/zero/1.0/) applies to the data made available in this article, unless otherwise stated. 
accuracy in various infectious pathologies, including sepsis, acute infectious endocarditis, and pancreatitis [7].

Procalcitonin, a 116-amino-acid peptide, which undergoes posttranslational proteolysis into calcitonin, is synthesized in $\mathrm{C}$ cells of the thyroid gland and secreted from leukocytes of the peripheral blood. The level of PCT increases (without an increase in calcitonin level) in the presence of bacterial lipopolysaccharides and cytokines that are associated with severe bacterial infections [8]. In contrast to this, there is minimal rise of PCT in patients infected with viruses [9]. Moreover, there is dramatic and quick increase in serum PCT levels after a single endotoxin injection $[9,10]$. This type of response to a bacterial stimulus makes PCT level a potentially sensitive marker of severe bacterial infections including meningitis.

Several studies have demonstrated the raised values of serum PCT in bacterial infections including meningitis [11]. Studies from adults have shown PCT as a powerful diagnostic test for the assessment of suspected meningitis, allowing rapid differentiation between bacterial and non-bacterial (mostly viral) aetiologies, and earlier initiation of appropriate and necessary therapies. The evidence suggests that while serum PCT offers a similar specificity to the traditionally used CSF markers of meningitis, it also confers a higher sensitivity allowing for a more accurate overall diagnosis in patients with suspected meningitis. Hence the use of PCT serum assays in adult patients with suspected meningitis has been recommended but there is lack of recommendation in children [2]. The reported results of these studies are varied and a consensus has yet to be reached on the diagnostic value of PCT in meningitis. Hence, we evaluated serum PCT as a marker to differentiate bacterial and non-bacterial meningitis in children and assessed its efficacy in comparison to other investigations.

\section{Methods}

This was a hospital-based cross-sectional study done in the department of Paediatrics, B P Koirala Institute of Health Sciences (BPKIHS), Nepal. Ethical clearance was obtained from institutional review committee. Fifty children aged 3 months to 15 years admitted during the study period (Aug 2016 - Dec 2016) with suspected meningitis were enrolled. Written informed consent was taken and those not giving consent, less than 3 months, more than 15 years, having secondary site of infection apart from meningitis or had received antibiotics for more than 3 days prior to admission were excluded. All the enrolled cases were worked-up and relevant diagnostic investigations like total/ differential leukocyte count, CSF analysis by lumbar puncture were done. Along with these investigations, another $2 \mathrm{ml}$ of blood was taken from each patient at the time of admission for serum PCT estimation which was performed on the fully-auto Chemiluminescence immunoassay (CLIA) analyzer Maglumi 1000 from Snibe Diagnostics with detection range of $0.13-100 \mathrm{ng} / \mathrm{ml}$. Meningitis was diagnosed according to history, physical examination, CSF laboratory findings. It was further defined as bacterial meningitis if CSF showed bacteria in gram staining and/or culture, predominantly neutrophilic cells, glucose levels less than two-third of blood glucose or elevated CSF protein (>45 mg/dl) despite receiving antibiotics for 1-3 days. Similarly, it was labelled as non-bacterial if CSF showed no growth of organisms, had predominantly lymphocytic counts, and normal $(15-45 \mathrm{mg} / \mathrm{dl})$ or slightly increased (up to $60 \mathrm{mg} / \mathrm{dl}$ ) protein. The studied patients were categorized according to the CSF bacteriological and cytochemical profile into two groups: Group I (Bacterial meningitis) and Group II (Non bacterial meningitis). The details (demography, clinical features, investigation results and outcome) were recorded in a predesigned proforma. Data were analyzed using SPSS 17.0 statistical software using descriptive and analytic statistics (chi-square tests, independent sample t test, Mann Whitney U test) with significance set at 5\%.

\section{Results}

Amongst the 50 patients enrolled in this study, 22 patients fulfilled the criteria for bacterial meningitis and 28 patients non-bacterial meningitis. The median age of the studied population was 24(Interquartile range $=$ $10.75-75)$ months and $60 \%$ were males. The common clinical presentations were fever (96\%), convulsions (58\%), and vomiting (40\%). The demographic and clinical profile of the 2 groups were comparable with no statistically significant difference (Table 1).

The cultured organisms from CSF were: Staphylococcus aureus (3), Acinetobacter sp. (3), Streptococcus pneumoniae (2), Enterococcus sp. (2), E coli (1). Eleven children had clinical presentation of meningitis but had received antibiotics for 1-3 days prior to admission. They were grouped as bacterial meningitis on the basis of other clinical features and CSF findings like leukocytosis with neutrophilic predominance, decreased glucose and/or elevated protein.

Serum PCT levels were significantly higher in bacterial meningitis group $($ median $=2.04(1.2-3.18) \mathrm{ng} / \mathrm{ml})$ compared to non-bacterial meningitis (median $=0.35$ $(0.18-0.35) \mathrm{ng} / \mathrm{ml}) ; p<0.001$.

Table 2 shows the comparison of the laboratory findings of blood and CSF between the two groups.

The sensitivity and specificity of serum PCT was found to be $95.45 \%$ (77.16-99.88) and $84.6 \%$ (63.11-93.94) respectively with accuracy of $88 \%$ (75.69-95.47). Procalcitonin showed maximum area under receiver operating characteristics (ROC) curve $0.991(0.974-1.00)(p<0.001)$ compared to total leukocyte count and CSF cytochemistry. 
Table 1 Demographic \& clinical profile of patients $(n=50)$

\begin{tabular}{llll}
\hline Characteristics & $\begin{array}{l}\text { Group I Bacterial } \\
\text { meningitis }(n=22)\end{array}$ & $\begin{array}{l}\text { Group II Non-bacterial } \\
\text { meningitis }(n=28)\end{array}$ & $0.89^{\#}$ \\
\hline Age (months) & $23.5(11.75-66)$ & $30(9.25-81)$ & $19(67.85 \%)$ \\
Sex: Male & $11(50 \%)$ & $9(32.15 \%)$ & $3(2-3.75)$ \\
$\quad$ Female & $11(50 \%)$ & $27(96.43 \%)$ & $0.20^{*}$ \\
IIIness duration (days) & $2.5(1.75-4.5)$ & $14(50 \%)$ & $0.34^{\#}$ \\
Fever & $21(95.46 \%)$ & $14(50 \%)$ & $0.19^{*}$ \\
Convulsions & $15(68.18 \%)$ & $7(25 \%)$ & $0.10^{*}$ \\
Vomiting & $6(27.28 \%)$ & $2(7.14 \%)$ & $0.32^{*}$ \\
Headache & $3(13.64 \%)$ & $1(3.57 \%)$ & $0.22^{*}$ \\
Loss of consciousness & $5(22.72 \%)$ & $7(25 \%)$ & $0.06^{*}$ \\
Neck pain & $8(36.36 \%)$ & $3(10.71 \%)$ & $0.59^{*}$ \\
Decreased feeding & $7(31.81 \%)$ & $13.39 \pm 2.18$ & $0.68^{*}$ \\
Excessive crying & $4(18.18 \%)$ & $6(21.43 \%)$ & $0.40^{\# \#}$ \\
GCS & $12.86 \pm 2.42$ & $3(10.71 \%)$ & $0.52^{*}$ \\
Neck stiffness & $10(45.45 \%)$ & $3(10.71 \%)$ & $0.62^{*}$ \\
Kernig's sign & $1(4.54 \%)$ & $5(17.86 \%)$ & $8(28.57 \%)$ \\
Brudzinski sign & $1(4.54 \%)$ & $5(17.86 \%)$ & $0.62^{*}$ \\
Raised Intracranial pressure & $5(22.72 \%)$ & & $0.67^{*}$ \\
ICU need & $5(22.72 \%)$ & $2(9.09 \%)$ & $0.64^{*}$ \\
Mechanical ventilation & $0.44^{*}$ \\
\hline
\end{tabular}

( ${ }^{*}$ Chi square test; ${ }^{\#}$ Mann Whitney $\mathrm{U}$ test; ${ }^{\# \#}$ Independent sample t test)

Table 3 shows the efficacy of PCT (with diagnostic cut-off point $>0.5 \mathrm{ng} / \mathrm{ml})$ compared to TLC $(>11,000 /$ $\mathrm{mm} 3$ ), CSF TLC (>10 cells $/ \mathrm{mm} 3$ ), CSF neutrophil count (>60\%), CSF glucose $(<60 \%$ of blood glucose) and CSF protein $(>45 \mathrm{mg} / \mathrm{dl}$ ) for diagnosis of bacterial meningitis.

\section{Discussion}

Early diagnosis of meningitis and differentiation of bacterial from non-bacterial meningitis plays a vital role in the emergency management of children with suspected meningitis. Since Assicot et al. first proposed serum PCT as an early marker of bacteremia in 1993, there have been various descriptive reports on PCT [12].
Procalcitonin has been demonstrated to be ideal marker with highest accuracy for bacterial infectionsallowing an early diagnosis, informing about the course and prognosis of the disease and facilitating therapeutic decisions $[13,14]$. Procalcitonin has been found to be more specific and sensitive marker of various infections like respiratory tract infections, meningitis, acute infectious endocarditis and pancreatitis [7]. Different studies have found its sensitivity and specificity ranging from 50 to $100 \%$ but there is still variation in choice of the "abnormal" cut-off values due to diverse age range and nature of the study populations in those studies [5].

Table 2 Laboratory findings of blood and cerebrospinal fluid $(n=50)$

\begin{tabular}{llll}
\hline Lab parameter & $\begin{array}{l}\text { Group I Bacterial } \\
\text { meningitis }(n=22)\end{array}$ & $\begin{array}{l}\text { Group II Non-bacterial } \\
\text { meningitis }(n=28)\end{array}$ \\
\hline Serum procalcitonin (PCT) $(\mathrm{ng} / \mathrm{ml})$ & $2.86 \pm 2.45$ & $0.38 \pm 0.24$ & $\begin{array}{l}P \text { value } \\
\text { Total leukocyte count (TLC) per cubic milimetre }\left(/ \mathrm{mm}^{3}\right)\end{array}$ \\
Neutrophil (\%) & $15,204.56 \pm 8075.98$ & $40,250 \pm 4074.45$ & $0.001^{\#}$ \\
CSF & $53.45 \pm 20.12$ & & $0.06^{\# \#}$ \\
TLC $\left(/ \mathrm{mm}^{3}\right)$ & & $12.15 \pm 18.55$ & $0.427^{\#}$ \\
Neutrophil (\%) & $28.59 \pm 73.38$ & $21.23 \pm 26.44$ & $0.056^{\#}$ \\
Glucose (\% of blood glucose) & $41.05 \pm 35.08$ & $39.08 \pm 14.79$ & $0.75^{\# \#}$ \\
Protein (mg/dl) & $42.18 \pm 12.86$ & $41.04 \pm 11.51$ & $0.001^{\#}$ \\
\hline
\end{tabular}

("Mann Whitney U test; ${ }^{\# \#}$ Independent sample t test) 
Table 3 Efficacy of serum procalcitonin, total leukocyte count \& cerebrospinal fluid cytochemistry in diagnosis of bacterial meningitis

\begin{tabular}{lllll}
\hline Test & Sensitivity & Specificity & $\begin{array}{l}\text { Area under curve } \\
\text { (95\% confidence interval) }\end{array}$ & $P$ value \\
\hline Procalcitonin & $95.45 \%$ & $84.6 \%$ & $0.991(0.974-1.00)$ & 0.001 \\
TLC & $81.8 \%$ & $50.0 \%$ & $0.679(0.523-0.835)$ & 0.034 \\
CSF & & & & $0.566(0.4-0.731)$ \\
TLC & $54.5 \%$ & $62.5 \%$ & $0.656(0.496-0.817)$ & 0.438 \\
Neutrophil & $27.3 \%$ & $88.0 \%$ & $0.537(0.37-0.704)$ & 0.064 \\
Glucose & $90.9 \%$ & $15.2 \%$ & $0.788(0.66-0.915)$ & 0.664 \\
Protein & $68.2 \%$ & $58.7 \%$ & & 0.001 \\
\hline
\end{tabular}

In this study we found serum PCT significantly higher in children with bacterial meningitis than non-bacterial meningitis. The mean PCT level in bacterial meningitis was $2.86 \pm 2.45 \mathrm{ng} / \mathrm{ml}$ while that in non-bacterial meningitis was $0.38 \pm 0.27 \mathrm{ng} / \mathrm{ml}(p<0.001)$. This result is similar to that obtained by other investigators where PCT concentration increased in bacterial meningitis but not in viral meningitis and inflammatory diseases [3, 8, 9, 15-21].

This increase in serum PCT in bacterial meningitis can be explained by the increase of calcitonin gene (CALC-I gene) expression and release of PCT from all parenchymal tissues and differentiated cell types throughout the body in presence of bacterial lipopolysaccharides and cytokines associated with severe bacterial infections $[8,16]$.

In healthy subjects, circulating levels of PCT are very low, usually below $0.01 \mathrm{ng} / \mathrm{ml}$ and in viral infection and inflammation, the concentrations increase slightly but rarely above $1.0 \mathrm{ng} / \mathrm{ml}$. [18] Gendrel et al. have demonstrated elevated PCT levels (mean level, $54.5 \mathrm{mg} / \mathrm{L}$; range, $4.8-110 \mathrm{mg} / \mathrm{L}$ ) in bacterial meningitis while low levels (mean level, $0.32 \mathrm{mg} / \mathrm{L}$; range, $0-1.7 \mathrm{mg} / \mathrm{L} ; \mathrm{P}$. .0001) in viral meningitis in children when there is zone of overlapping values in CSF cells and proteins and CRP $[9,16]$. Ibrahim et al. demonstrated cut off point > $0.5 \mathrm{ng} / \mathrm{ml}$ showing positive correlation for differentiating acute bacterial meningitis from non-bacterial origin [8].

It has long been known that leukocyte count can differentiate bacterial and non-bacterial infection including meningitis [3, 4]. Similarly CSF cytochemistry is used in ruling out meningitis cases [14]. In our study, TLC was significantly higher in bacterial meningitis but CSF parameters apart from protein had no significant difference between the two groups. This may be explained by lack of clear demarcation in cut-off for bacterial meningitis and also possible lysis of cells due to delayed processing or clearance with start of antibiotics in some cases.

This result is in agreement with other studies where leukocytosis was valuable in distinguishing between bacterial and non-bacterial infections but not an independent predictor of serious bacterial infection like PCT and CRP $[8,21-23]$. In our study, the sensitivity and specificity of
PCT (with diagnostic cut-off point $>0.5 \mathrm{ng} / \mathrm{ml}$ ) were 95.45\% (77.16-99.88) and 84.6\% (63.11-93.94) respectively with accuracy of $88 \%$ (75.69-95.47) and maximum area coverage in receiver operative characteristic curve (ROC) $0.991(0.974-1.00)(p<0.001)$ as compared to TLC and CSF cytochemistry. Similarly, Usama M pointed out PCT concentration $>2 \mathrm{ng} / \mathrm{ml}$ had $100 \%$ sensitivity and negative predictive value but only $66 \%$ specificity and $68 \%$ positive predictive value for bacterial meningitis [5]. Procalcitonin has been found to have better specificity, sensitivity, predictive value and likelihood ratio than CRP, interleukin 6 and interferon-alpha in children for distinguishing between bacterial and viral infections in other studies from various parts of the world [2, 4, 8, 9, 17]. A meta-analysis showed serum PCT to be very accurate for rapid differentiation of the aetiology of paediatric meningitis with pooled sensitivity and specificity of $0.96(95 \%$ $\mathrm{CI}=0.92-0.98)$ and $0.89(95 \% \mathrm{CI}=0.86-0.92)$ respectively [24]. CRP was not measured in our study but various studies have compared PCT with CRP and concluded the superiority of PCT over CRP in diagnosis.

Potential limitations of our study were that we could not measure serum PCT in follow-up due to the high cost of procalctionin kit. This would have helped to document the change in PCT with start of treatment for evaluation of treatment efficacy and further prognostication. Other studies have shown decrease of PCT over time with antibiotics treatment in bacterial meningitis [25].

Thus, serum PCT can act as a more sensitive and specific diagnostic tool in early differentiation of bacterial from non-bacterial meningitis in children and thereby help in better management of these children in emergency.

\section{Conclusions}

Serum PCT has high sensitivity and specificity for early diagnosis of bacterial meningitis in children. Hence it can be a useful adjunct in differentiating bacterial and non-bacterial meningitis for prompt and better management of the children. 


\section{Abbreviations}

BPKIHS: B P Koirala Institute of Health Sciences; CLIA: Chemiluminescence immunoassay; CNS: Central nervous system; CRP : C reactive protein; CSF: Cerebrospinal fluid; CT: Computed Tomography; ELISA: Enzyme linked immunosorbent assay; $G$ stain: Gram stain; IgM: Immunoglobulin M; IL: Interleukin; JE: Japanese encephalitis; MRI: Magnetic Resonance Imaging; PCT: Procalcitonin; PICU: Pediatric Intensive Care Unit; PMN: Polymorph; ROC: Receiver Operative Characteristic curve; TLC : Total leukocyte count; TNF: Tumor necrosis factor; WBC: White blood cell; ZN stain: Zeihl Neelsen stain

\section{Acknowledgements}

We would like to acknowledge BPKIHS Research Committee and Institutional Review Committee for providing the BPKIHS research grant to conduct this study. We owe special thanks to Mr. D D Baral, biostatistician, for his help in statistical analysis.

\section{Funding}

Funding for the procalcitonin kit was obtained from BPKIHS research committee (BPKIHS Research Grant).

\section{Availability of data and materials}

The datasets used and/or analyzed during the current study are available from the corresponding author on reasonable request.

\section{Authors' contributions}

SC conceptualized and designed the study, collected data, analysed data, drafted the initial manuscript. NKB analysed, redesigned, revised and critically reviewed the manuscript. ML analysed, revised and critically reviewed the manuscript. RKC collected data, analysed data and reviewed the manuscript. BK analysed, redesigned, revised and critically reviewed the manuscript. All authors read and approved the final manuscript as submitted.

\section{Ethics approval and consent to participate}

Ethical approval was taken from the ethics committee of instituteInstitutional Review Committee (IRC) BPKIHS. Written informed consent was obtained from each patient/guardian for participation in the study.

\section{Consent for publication}

Written informed consent was taken from patient/guardian for publication.

\section{Competing interests}

The authors declare that they have no competing interests.

\section{Publisher's Note}

Springer Nature remains neutral with regard to jurisdictional claims in published maps and institutional affiliations.

Received: 22 July 2018 Accepted: 19 October 2018

Published online: 02 November 2018

\section{References}

1. Holmquist L, Russo CA, Elixhauser A. Meningitis-Related Hospitalizations in the United States, 2006: Statistical Brief \#57. In: Healthcare Cost and Utilization Project (HCUP) Statistical Briefs. 2008.

2. Vikse J, Henry BM, Roy J, Ramakrishnan PK, Tomaszewski KA, Walocha JA. The role of serum procalcitonin in the diagnosis of bacterial meningitis in adults : a systematic review and meta-analysis. Int J Infect Dis. 2015;38:68-76.

3. Scheld WM, Koedel U, Nathan B, Pfister HW. Pathophysiology of bacterial meningitis: mechanism(s) of neuronal injury. J Infect Dis. 2002;186(Suppl 2): S225-33.

4. Dubos F, Korczowski B, Aygun DA, Martinot A, Prat C, Galetto-Lacour A, et al. Serum Procalcitonin level and other biological markers to distinguish between bacterial and aseptic meningitis in children. Arch Pediatr Adolesc Med. 2008:162(12):1157.

5. Alkholi UM, Al-monem NA, El-Azim AAA, Sultan MH. Serum Procalcitonin in viral and bacterial meningitis. J Glob Infect Dis. 2011;3(1):14-8.

6. Schuetz P, Christ-Crain M, Müller B. Procalcitonin and other biomarkers to improve assessment and antibiotic stewardship in infections--hope for hype? Swiss Med Wkly. 2009;139(23-24):318-26.

7. Carrol ED, Thomson APJ, Hart CA. Procalcitonin as a marker of sepsis. Int J Antimicrob Agents. 2002;20:1-9.
8. Abdel-Wahab AA, Ibrahim AS. Diagnostic value of serum procalcitonin levels in children with meningitis: a comparison with blood leukocyte count and C-reactive protein. J Pak Med Assoc. 2011;61(4):346-51.

9. Gendrel D, Raymond J, Assicot M, Moulin F, Iniguez JL, Lebon P, et al. Measurement of procalcitonin levels in children with bacterial or viral meningitis. Clin Infect Dis. 1997;24(6):1240-2.

10. Taskin E, Turgut M, Kilic M, Akbulut H, Aygun AD. Serum procalcitonin and cerebrospinal fluid cytokines level in children with meningitis. Mediat Inflamm. 2004;13(4):269-73.

11. Dubos F, Korczowski B, Aygun DA, Martinot A, Prat C, Galetto-lacour A, et al. Distinguishing between bacterial and aseptic meningitis in children : European comparison of two clinical decision rules. Arch Dis Child. 2010;95:963-7.

12. Assicot M, Gendrel D, Carsin H, Raymond J, Guilbaud J, Bohuon C. High serum procalcitonin concentrations in patients with sepsis and infection. Lancet. 1993:341:515-8.

13. Christ-Crain M, Muller B. Procalcitonin in bacterial infections-hype, hope, more or less? Swiss Med Wkly. 2005;135:451-60.

14. Meisner M. Update on Procalcitonin measurements. Ann Lab Med. 2014;34: 263-73.

15. Umran RMR, Radhi NH. Diagnostic value of serum Procalcitonin level in differentiating bacterial from nonbacterial meningitis in children. Iran J Pediatr. 2014:24(6):739-44

16. Gendrel D, Assicot M, Raymond J, Moulin F, Francoual C, Badoual J, et al. Procalcitonin as a marker for the early diagnosis of neonatal infection. J Pediatr. 1996;128:570-3.

17. Liu CF, Xu W, Cai XX. Serum procalcitonin levels in children with bacterial or viral meningitis. Zongguo Dang Dai Er Ke Za. 2006;8:17-20.

18. Mills GD, Lala HM, Oehley MR, Craig AB, Barratt K, Hood D, et al. Elevated procalcitonin as a diagnostic marker in meningiococcal disease. Eur J Clin Microbiol Infect Dis. 2006;25:501-9.

19. Korczowski B, Bijos A, Rybak A. Procalcitonin in diagnosis of purulent and aseptic meningitis in children. Pol Merkur Lekarski. 2000;9(53):755-7.

20. Prat C, Dominguez J, Rodrigo C, et al. Use of quantitative and semiquantitative procalcitonin measurements to identify children with sepsis and meningitis. Eur J Clin Microbiol Infect Dis. 2004;23(2):136-8.

21. Mary R, Veinberg F, Coudrec R. Acute meningitides, acute phase proteins and procalcitonin. Ann Bio Clin (Paris). 2003:61(2):127-37.

22. Mehanic S, Baljic R. The importance of serum Procalcitonin in diagnosis and treatment of serious bacterial infections and Sepsis. Mater Sociomed. 2013: 25(4):277-81.

23. Lacour AG, Zamora SA, Gervaix A. A score identifying serious bacterial infections in children with fever without source. Pediatr Infect Dis J. 2008:27:654-6.

24. Henry BM, Roy J, Ramakrishnan PK, Vikse J, Tomaszewski KA, Walocha JA. Procalcitonin as a serum biomarker for differentiation of bacterial meningitis from viral meningitis in children: evidence from a meta-analysis. Clin Pediatr (Phila). 2016:55(8):749-64.

25. Viallon A. Guyomarc'h P, Guyomarc'h S, tardy B, Robert F, Marjollet O, et al. decrease of serum procalcitonin levels over time during treatment of acute bacterial meningitis. Crit Care. 2005;9:R344-50.
Ready to submit your research? Choose BMC and benefit from:

- fast, convenient online submission

- thorough peer review by experienced researchers in your field

- rapid publication on acceptance

- support for research data, including large and complex data types

- gold Open Access which fosters wider collaboration and increased citations

- maximum visibility for your research: over $100 \mathrm{M}$ website views per year

At BMC, research is always in progress.

Learn more biomedcentral.com/submission 